\title{
REVIEW
}

\section{LEPROSY NEPHROPATHY: A REVIEW OF CLINICAL AND HISTOPATHOLOGICAL FEATURES}

\author{
Geraldo Bezerra da SILVA JUNIOR(1), Elizabeth De Francesco DAHER(2), Roberto da Justa PIRES NETO(3), Eanes Delgado Barros PEREIRA(2),
} Gdayllon Cavalcante MENESES(4), Sônia Maria Holanda Almeida ARAÚJO(1) \& Elvino José Guardão BARROS(5)

\begin{abstract}
SUMMARY
Leprosy is a chronic disease caused by Mycobacterium leprae, highly incapacitating, and with systemic involvement in some cases. Renal involvement has been reported in all forms of the disease, and it is more frequent in multibacillary forms. The clinical presentation is variable and is determined by the host immunologic system reaction to the bacilli. During the course of the disease there are the so called reactional states, in which the immune system reacts against the bacilli, exacerbating the clinical manifestations. Different renal lesions have been described in leprosy, including acute and chronic glomerulonephritis, interstitial nephritis, secondary amyloidosis and pyelonephritis. The exact mechanism that leads to glomerulonephritis in leprosy is not completely understood. Leprosy treatment includes rifampicin, dapsone and clofazimine. Prednisone and non-steroidal anti-inflammatory drugs may be used to control acute immunological episodes.
\end{abstract}

KEYWORDS: Leprosy; Hansen disease; Kidney dysfunction; Chronic kidney disease; Glomerulonephritis.

\section{INTRODUCTION}

Leprosy is a chronic disease caused by Mycobacterium leprae, an acid-fast bacilli, intracellular parasite, with predilection to Schwann cell and skin. The disease is highly incapacitating, and systemic involvement is reported in some cases ${ }^{45}$. Renal involvement has been reported in all forms of the disease, and it is more frequent in multibacillary forms ${ }^{51}$. The present paper presents a review of the clinical and histopathological aspects of leprosy nephropathy.

EPIDEMIOLOGY: The number of leprosy patients is estimated to be between 10 and 15 million, distributed across more than 100 countries. In 2007, a total of 254,525 new cases were reported all over the world ${ }^{45}$. Brazil is considered as having a high endemicity index and is the country with the second highest number of cases, with 37,610 new cases registered in $2009^{58}$. Leprosy prevalence in Brazil was reduced by $85 \%$, going from 17 to 3.8 cases $/ 10,000$ population in the period between 1985 and $2001^{35}$.

LEPROSY PATHOPHYSIOLOGY: Infected persons with $M$. leprae are thought not to develop clinical disease. M. leprae is slow growing and the incubation period is long at 2-12 years. The $M$. leprae has a high infective power, but low pathogenic power ${ }^{3}$. Person-to-person spread via nasal droplets is believed to be the main route of leprosy transmission. Most people with leprosy are non-infectious. Patients with lepromatous leprosy excrete $M$. leprae from their nasal mucosa and skin and are infectious before starting treatment with multidrug therapy. Contacts of these patients are, therefore, at increased risk of developing the disease. There may be a genetic predisposition to disease manifestation. Infection with $M$. leprae leads to chronic granulomatous inflammation in skin and peripheral nerves ${ }^{46}$. Single-nucleotide polymorphism (SNP) association studies showed a low lymphotoxin- $\alpha$ (LTA)-producing allele as a major genetic risk factor for early onset leprosy. Other SNPs to be associated with disease and/or the development of reactions in several genes, such as vitamin D receptor (VDR), TNF- $\alpha$, IL-10, IFN- $\gamma$, HLA genes, and TLR1 have also been suggested ${ }^{6}$. The type of leprosy that patients develop is determined by their cell-mediated immune response to infection. Patients with tuberculoid disease have a good cell-mediated immune response and few lesions with no detectable mycobacteria. Patients with lepromatous leprosy are anergic towards $M$. leprae and have multiple lesions with mycobacteria present ${ }^{46}$. Schwann cells (SCs) are a major target for infection by $M$. leprae leading to nerve injury, demyelination, and consequent disability. Binding of $M$. leprae to SCs induces demyelination and loss of axonal conductance. Macrophages are one of the most abundant host cells to come in contact with mycobacteria. Phagocytosis of M. leprae by monocyte-derived macrophages can be mediated by complement receptors CR1 (CD35), $\mathrm{CR} 3$ (CD11b/CD18), and CR4 (CD11c/CD18) and is regulated by protein kinase $^{6}$. The inflammation present in nerves is driven by mycobacterial antigens that activate a destructive inflammatory immune response mediated by CD4+ cells and macrophages, and with involvement of multiple pro-inflammatory cytokines, such as tumor necrosis factor $\alpha^{46}$. In the tuberculoid lesions there is a predominance of CD4+ auxiliary

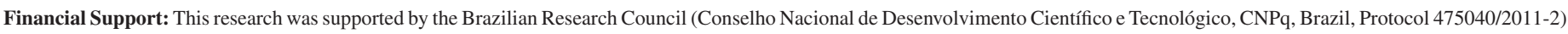
(1) School of Medicine, Master in Collective Health, Health Sciences Center, University of Fortaleza. Fortaleza, Ceará, Brazil.

(2) Post-Graduation Program in Medical Sciences, Department of Internal Medicine, Federal University of Ceará. Fortaleza, Ceará, Brazil.

(3) Department of Community Health, School of Medicine, Federal University of Ceará. Fortaleza, Ceará, Brazil.

(4) School of Pharmacy, Federal University of Ceará. Fortaleza, Ceará, Brazil.

(5) Department of Internal Medicine, School of Medicine, Federal University of Rio Grande do Sul. Porto Alegre, Rio Grande do Sul, Brazil.

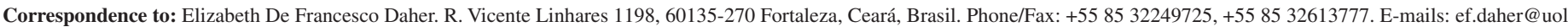
com.br, geraldobezerrajr@yahoo.com.br, elvino.barros@gmail.com,robertojusta@secrel.com.br, eanes@fortalnet.com.br, gdayllon@yahoo.com.br, soniaholanda.unifor@gmail.com 


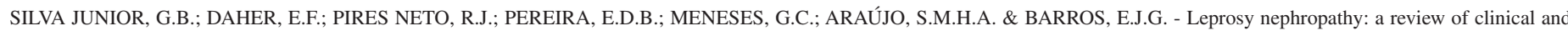
histopathological features. Rev. Inst. Med. Trop. Sao Paulo, 57(1): 15-20, 2015

T cells and Th1 cytokines such as IL-2 and IFN-gamma, while in lepromatous (Virchowian) lesions suppressant T cells, CD8+, and Th2 cytokines such as IL-4, IL-5 and IL- $10^{3}$ predominate. In the tuberculoid type, the exacerbation of cellular immunity and the production of pro-inflammatory cytokines (IL-1 and TNF-alpha) prevents the bacilli proliferation, but can cause injury to the host due to the lack of regulator factors. In the Virchowian type, the production of PGL-1 (phenolic glycolipid antigen-1) and LAM (lipoarabinomannan) antigens by the bacilli, inside macrophages, favors the escapade of the bacilli from the intramacrophage oxidation, because these antigens have a suppressant effect over macrophage activity, and then favors bacilli proliferation ${ }^{3}$.

CLINICAL MANIFESTATIONS: Leprosy is characterized by tegumentary lesions and nervous system injury. The clinical presentation is variable and is determined by the host immunologic system reaction to the bacilli. During the course of the disease there are the so called reactional states, in which the immune system reacts against the bacilli, exacerbating the clinical manifestations. There are two types of reactional states: reversal reaction (type I), which is more common in the paucibacillary forms, and erythema nodosum (type II), more common in multibacillary forms ${ }^{45}$. The disease is divided into four forms, according to the criteria established by the World Health Organization: indeterminate, tuberculoid, dimorphous and virchowian. The diagnosis and classification are based on clinical findings and complementary tests, such as baciloscopy, which allow the classification in multibacillary and paucibacillary.

EFFECTS OF IMMUNOSUPPRESSION, HIV AND TRANSPLANT IN LEPROSY: At the beginning of the HIV epidemic there was a fear that HIV infection could increase the risk of leprosy development or that the co-infection (HIV-leprosy) would cause a more severe disease ${ }^{46}$. This hypothesis was not confirmed, since some studies have shown that patients receiving highly active antiretroviral therapy are more likely to develop borderline tuberculoid leprosy than other types of leprosy ${ }^{46}$. HIV infection has not been reported to increase susceptibility to leprosy, impact on immune response to $M$. leprae, or to have a significant effect on the pathogenesis of neural or skin lesions to date. The initiation of antiretroviral treatment has been reported to be associated with activation of subclinical $M$. leprae infection and exacerbation of existing leprosy lesions (type I reaction) likely as part of immune reconstitution inflammatory syndrome ${ }^{6}$. Leprosy has also been reported to occur after organ transplantations, but this is not frequent and immunosuppressant therapy did not seem to affect the course of leprosy manifestations $\mathbf{s}^{4,55}$. The course of leprosy seems not to be affected by immunosuppression ${ }^{55}$.

RENAL INVOLVEMENT: Renal involvement in leprosy was first described in the beginning of the XX century, through necropsy studies, in which glomerulonephritis and tubulointerstitial lesions were described $^{28,36}$. Different renal lesions have been described in leprosy, including acute and chronic glomerulonephritis, interstitial nephritis, secondary amyloidosis and pyelonephritis ${ }^{19,41,48}$. There are several reports of renal involvement in leprosy, as summarized in Table 1.

The exact mechanism that leads to glomerulonephritis in leprosy is not completely understood. The $M$. leprae may be directly involved in renal injury and it has already been detected in glomeruli of infected patients. The glomerular lesion is probably caused by immunologic mechanism, with complement decrease and immune complexes deposition in glomerular basement membrane, subendothelial and subepithelial space, detected by electronic microscopy ${ }^{19,41,48}$. Some studies have also detected mesangial proliferation and the presence of IgA in the mesangial area ${ }^{53}$. The pathophysiology of renal involvement in leprosy is illustrated in Fig. 1.

A consistent relation between the lepromatous form, erythema nodosum and kidney disease has been described in some studies ${ }^{18}$. Although leprosy nephropathy is more frequent in the multibacillary form, it can also occur in other forms and in the absence of the reactional state ${ }^{19}$.

A large retrospective study with 923 leprosy patients followed in a tertiary hospital in Brazil found acute kidney injury in 3.8\% of cases, and $65 \%$ of them had the multibacillary form. Risk factors for kidney injury were reactional state, multibacillary classification and advanced age ${ }^{10}$.

RENAL LESION MECHANISM: Erythema nodosum leprosum is a reactional state characterized by immune complexes formation in circulation and subsequent deposition in vessels and tissues. Sometimes they are determined by Hansen's bacilli antigens which are released into circulation after the beginning of antibiotic therapy ${ }^{9}$. The antigens are recognized by host antibodies, and then immune complexes are formed. After this, immune complexes can deposit in the glomerulus or can occur by the formation of immune complexes in situ. However, not all glomerulonephritis in leprosy are associated with erythema nodosum, which raises the hypothesis of multifactorial influence in the development of leprosy nephropathy. In the virchowian form there is a cellular immunity decrease and a hyperactivation of humoral immunity, which makes the patient susceptible to the formation of immune complexes ${ }^{30}$.

The antigen that can induce the formation of immune complexes can originate from Hansen's bacilli or even from therapeutic agents. Anti-dapsone antibodies have been detected in the circulation of leprosy patients. Auto-antibodies have also been described in leprosy, mainly cryoglobulins with $\operatorname{IgG}$ and $\operatorname{IgM}^{13}$.

Some patients with lower limb ulcers and secondary infections by Streptococcus presented a higher frequency of glomerulonephritis ${ }^{7}$.

URINARY FINDINGS: Hematuria has been described in leprosy, mainly in the virchowian form and during erythema nodosum state, even in the absence of evident glomerulonephritis ${ }^{18}$. Microscopic hematuria is found in $12-16 \%$ of cases, which is higher than what is found in the general population $(0.5-2 \%)^{7,17,57}$. This complication can disappear after a few months of specific treatment ${ }^{9}$.

Proteinuria has been described in several studies and its prevalence varies from 2.1 to $68 \%$, and it is also more frequent in the multibacillary forms $\mathrm{s}^{7,27,29,39,50}$. Proteinuria varies from 0.4 to $8.9 \mathrm{~g} /$ day. Nephrotic syndrome is not frequent in leprosy. RAMANUJAM et $a l .{ }^{44}$ reported five cases in the virchowian form, four were in reactional state and only two had amyloid deposits detected.

Other urinary abnormalities, such as cylindruria and leukocyturia, are more frequently found in the virchowian form with reactional state. In the milder forms these abnormalities are uncommon ${ }^{44}$.

GLOMERULONEPHRITIS: Glomerulonephritis represents the 


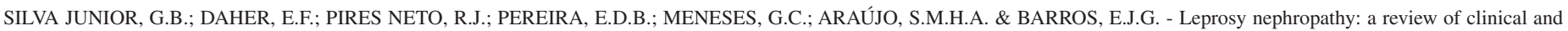
histopathological features. Rev. Inst. Med. Trop. Sao Paulo, 57(1): 15-20, 2015.

Table 1

Studies and case reports on kidney involvement in leprosy

\begin{tabular}{|c|c|c|c|c|c|}
\hline Reference & $\begin{array}{c}\text { Number of } \\
\text { cases }\end{array}$ & Age (years) & Gender & Clinical picture & Kidney biopsy \\
\hline Iveson $(1975)^{23}$ & 1 & 19 & M & $\begin{array}{l}\text { Poliarthritis } \\
\text { AKI }\end{array}$ & Diffuse proliferative lesion \\
\hline Date $(1977)^{12}$ & 19 & & & $\begin{array}{l}\text { Proteinuria } \\
\text { Hematuria }\end{array}$ & $\begin{array}{c}\text { Diffuse proliferative lesion } \\
\text { Amyloidosis }\end{array}$ \\
\hline Singhal $(1977)^{53}$ & 3 & & & AKI & $\begin{array}{l}\text { Acute tubular necrosis } \\
\text { Crescentic nephropathy }\end{array}$ \\
\hline Gupta $(1981)^{20}$ & 21 & & & & $\begin{array}{c}\text { Diffuse proliferative lesion } \\
\text { Amyloidosis } \\
\end{array}$ \\
\hline Phadnis $(1982)^{42}$ & 50 & & & & $\begin{array}{c}\text { Membranoproliferative nephropathy } \\
\text { Membranous nephropathy } \\
\text { Amyloidosis }\end{array}$ \\
\hline Chugh $(1983)^{7}$ & 60 & & & $\begin{array}{c}\text { Proteinuria } \\
\text { Hematuria } \\
\text { AKI }\end{array}$ & $\begin{array}{c}\text { Mesangial proliferative lesion }(8.3 \%) \\
\text { Diffuse proliferative lesion }(8.3 \%) \\
\text { Amyloidosis }(5 \%)\end{array}$ \\
\hline Jayalakshmi $(1987)^{25}$ & 35 & 74 & & AKI & $\begin{array}{c}\text { Interstitial nephritis } \\
\text { Amyloidosis } \\
\end{array}$ \\
\hline Al-Mohaya $(1988)^{2}$ & 1 & 17 & M & Proteinuria & Membranoproliferative nephropathy \\
\hline Madiwale $(1994)^{34}$ & 2 & $30-45$ & M & $\begin{array}{l}\text { Proteinuria } \\
\text { Hematuria } \\
\end{array}$ & Crescentic nephropathy \\
\hline Ahsan $(1995)^{1}$ & 1 & 79 & M & $\begin{array}{c}\text { Hematuria } \\
\text { AKI } \\
\end{array}$ & Diffuse proliferative lesion \\
\hline Lau $(1995)^{31}$ & 1 & 71 & M & $\begin{array}{c}\text { AKI } \\
\text { Drug hepatitis } \\
\end{array}$ & Interstitial nephritis \\
\hline Nakayama $(2001)^{38}$ & 199 & $47-74$ & M $(79.3 \%)$ & & $\begin{array}{c}\text { Amyloidosis (31\%) } \\
\text { Diffuse proliferative lesion (5\%); } \\
\text { Focal proliferative (4\%); } \\
\text { Membranoproliferative (2\%); } \\
\text { Membranous (1\%); } \\
\text { Mesangial proliferative lesion }(0.5 \%) \\
\text { Glomerular sclerosis }(11 \%) \\
\text { Tubulo-interstitial nephritis }(9 \%) \\
\text { Granulomata (1\%) }\end{array}$ \\
\hline Oliveira $(2008)^{40}$ & 59 & $43 \pm 15$ & $\mathrm{M}(51 \%)$ & $\begin{array}{l}\text { Concentration defect }(84 \%) \\
\text { Acidification defect }(30 \%) \\
\text { Function loss }(50 \%) \\
\end{array}$ & ( \\
\hline Sharma $(2010)^{49}$ & 1 & 25 & $\mathrm{~F}$ & $\begin{array}{c}\text { AKI } \\
\text { Proteinuria } \\
\end{array}$ & Crescentic nephropathy \\
\hline Silva Junior $(2010)^{52}$ & 1 & 58 & $\mathrm{M}$ & CKD & AA Amyloidosis \\
\hline Daher $(2011)^{10}$ & 923 & $41 \pm 19$ & $\mathrm{M}(53.3 \%)$ & $\begin{array}{c}\text { Proteinuria }(4.8 \%) \\
\text { Hematuria }(6.8 \%) \\
\text { Function loss }(3.8 \%) \\
\end{array}$ & No \\
\hline
\end{tabular}

M: Male; AKI: Acute kidney injury; CKD: Chronic kidney disease.

most frequent type of kidney disease in leprosy. In renal biopsy studies glomerulonephritis was found in more than $30 \%$ of patients ${ }^{30}$, which is higher than what is found in necropsy studies $(7 \%)^{13}$. In the multibacillary form, the prevalence of glomerulonephritis is higher ${ }^{8}$. Erythema nodosum has a strong correlation with the occurrence of glomerulonephritis, although there are some reports of its occurrence in reactional state type $\mathrm{I}^{7,9}$. Almost all kinds of glomerulonephritis have been described in leprosy $y^{7,13}$, and there is no specific histopathological pattern in leprosy nephropathy. There is a discrete predominance of membranoproliferative glomerulonephritis, which are in general associated with infectious disease-associated nephropathies ${ }^{20,24,42,49}$.

HISTOPATHOLOGICAL FINDINGS: The diversity of histopathological lesions found in leprosy suggests a heterogeneous 


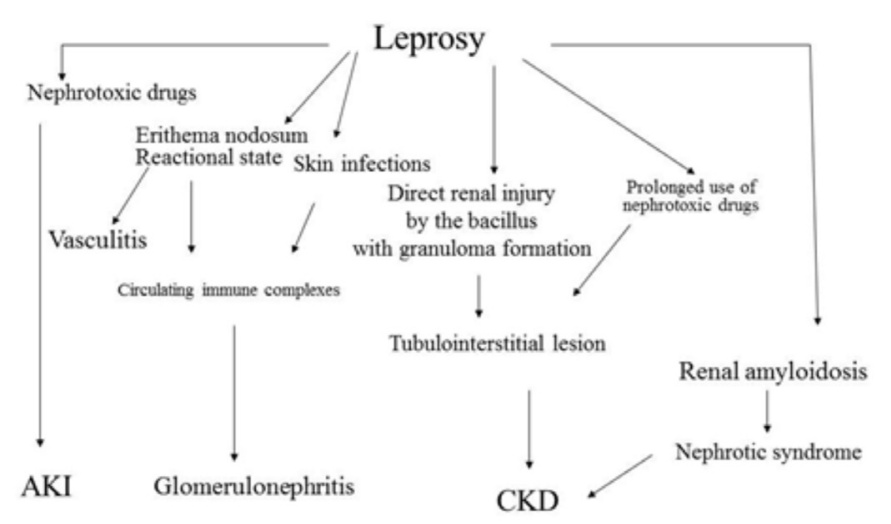

Fig. 1 - Pathophysiology of renal involvement in leprosy. AKI = acute kidney injury; CKD $=$ chronic kidney disease.

disease but not necessarily with different etiologies ${ }^{13}$. Immunohistochemical studies with renal tissue have identified the presence of granular deposits of $\operatorname{IgG}$ and $\mathrm{C} 3$, and less frequently $\operatorname{IgA}$, $\operatorname{IgM}$ and fibrin in the mesangium and in the glomerular capillaries, which is characterized by immune complex deposits or in situ formation. Electronic microscopy confirms the presence of dense granular deposits in mesangial-subendothelial and subepithelial regions ${ }^{14,26}$. Complement consumption in some cases reinforces the hypothesis of an immune complex-mediated disease ${ }^{30}$.

A study by GROVER et al. ${ }^{19}$, with 72 leprosy patients undergoing renal biopsy found the following histopathological patterns: membranous nephropathy $(31.5 \%)$ and mesangioproliferative glomerulonephritis (11.1\%). VALLÉS et al. ${ }^{56}$ reported one case of IgA nephropathy in a patient with the virchowian form, with reduction in glomerular filtration rate.

Several renal biopsy studies have been performed in leprosy. JOHNY et al. ${ }^{26}$ performed renal biopsies in 35 patients with leprosy and identified histological abnormalities in $45 \%$ of them, and the most frequent was proliferative glomerulonephritis. GUPTA et al. ${ }^{20}$ performed renal biopsies in 21 patients with virchowian leprosy, and found proliferative glomerulonephritis in 13 of them. GROVER et al. ${ }^{19}$, in a study with 54 renal biopsies found 12 cases $(22.2 \%)$ of diffuse proliferative glomerulonephritis (11 virchowian and one tuberculoid). They also found two cases of rapidly progressive glomerulonephritis, with acute kidney injury. Membranous nephropathy was found in 17 cases (31.5\%). PHADNIS et al. ${ }^{42}$ performed 50 renal biopsies and identified membranous nephropathy in two cases and membranoproliferative glomerulonephritis in six cases, of whom 45 had the lepromatous form and had reactional state. Interstitial nephritis was observed in 10 patients and amyloidosis in one case. Chronic kidney disease caused by secondary amyloidosis has also been described in leprosy ${ }^{52}$ (Fig. 2).

TUBULOINTERSTITIAL LESION: Interstitial nephritis is one of the most common histological findings in leprosy $y^{12,20,37}$. This has been described in patients with lepromatous leprosy, and is present in more than $20 \%$ of cases $^{19}$. It seems to be related to disease duration and the long-term treatment with nephrotoxic drugs ${ }^{26}$.

The identification of specific lesions in leprosy is described as the presence of granulomas in renal interstitium, with evidence of

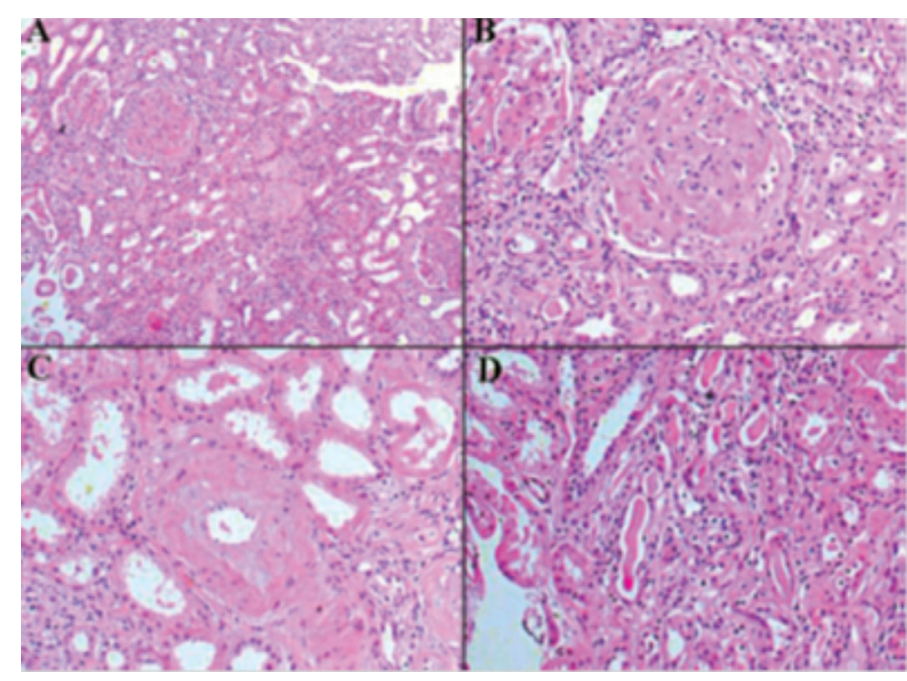

Fig. 2 - Kidney biopsy from a patient with leprosy and chronic kidney disease showing amyloid deposits (A), H\&E, x200; glomeruli without mesangial proliferation, with amyloid deposit in mesangium, H\&E, x400; amyloid deposit, H\&E x200; tubules without abnormalities, H\&E x200. Reprinted from Silva Junior et al. Rev Soc Bras Med Trop. 2010;43:474-6. ${ }^{52}$

mononuclear cells with vacuolized cytoplasm, without the presence of Hansen's bacillii ${ }^{43,47}$. Epithelioid granuloma and the Hansen's bacilli have already been detected in renal parenchyma ${ }^{38}$. The low incidence of granulomas in renal tissue is due to the fact that renal tissue presents a resistance to $M$. leprae or the fact that the bacteria has a low affinity to renal tissue ${ }^{42}$.

The occurrence of tubular dysfunction is frequent, varying from 25 to $85 \%$ of cases, in both multibacillary and paucibacillary forms ${ }^{7,40}$. Urinary acidification defect has been described in 20 to $32 \%$ of patients, and urinary concentration defect in $85 \%$ of cases ${ }^{16,40}$. Renal tubular acidosis has also been described ${ }^{16,21,40}$.

CHRONIC KIDNEY DISEASE: Chronic kidney disease (CKD) has been reported as one of the causes of death in leprosy, mainly in the first studies of leprosy nephropathy ${ }^{5,28,36,43}$. CKD is mainly caused by amyloidosis and is also more frequent in the virchowian form ${ }^{26,33,52}$. It has also been reported in patients with the tuberculoid form ${ }^{33}$. A correlation between the duration of the disease and the development of amyloidosis has not been observed ${ }^{26}$. A positive correlation was detected between the occurrence of erythema nodosum and secondary amyloidosis in leprosy ${ }^{15,32,33}$. Serum levels of amyloid protein A increases in erythema nodosum episodes and remains high for several months. LOMONTE et $a l .{ }^{32}$ described the evolution of eight patients with leprosy who developed $\mathrm{CKD}$ and required renal replacement therapy.

DRUGS TOXICITY: Despite not being common, renal abnormalities due to leprosy specific treatment have been described. There are reports on acute tubular necrosis, interstitial nephritis and papillary necrosis causing acute kidney injury in leprosy $y^{7,15}$.

Acute kidney injury can occur due to interstitial nephritis secondary to rifampicin use, which is more common with higher doses (900$1200 \mathrm{mg}$ ) than the usual $(450-600 \mathrm{mg})^{22}$. Dapsone can induce hemolysis and intravascular coagulation, which can lead to acute tubular necrosis ${ }^{54}$. 
SILVA JUNIOR, G.B.; DAHER, E.F.; PIRES NETO, R.J.; PEREIRA, E.D.B.; MENESES, G.C.; ARAÚJO, S.M.H.A. \& BARROS, E.J.G. - Leprosy nephropathy: a review of clinical and histopathological features. Rev. Inst. Med. Trop. Sao Paulo, 57(1): 15-20, 2015.

TREATMENT: Leprosy treatment encompasses specific therapy to overturn $M$. leprae, avoid immunological complications and prevent physical deformities, simultaneously promoting physical and psychosocial rehabilitation. Additionally, health authority notification is mandatory ${ }^{35}$. WHO-standardized leprosy therapy includes rifampicin, dapsone and clofazimine. Prednisone (1 to $2 \mathrm{mg} / \mathrm{kg} / \mathrm{day}$ ) and nonsteroidal anti-inflammatory drugs (NSAI) may be used to control acute immunological episodes. Erythema nodosum leprosum may sometimes have a protracted course (months, or years) and is usually treated with NSAI, steroids, thalidomide, clofazimine and pentoxiphyline. It must be kept in mind that all are potentially nephrotoxic. Hemodialysis or kidney transplant are alternatives in treating leprosy ESRD. Post-transplant immunosuppression apparently does not modify leprosy response to drugs. However, acute transitory deterioration of its course has been reported ${ }^{4}$.

\section{CONCLUSION}

Renal involvement is an important complication in leprosy, which should be investigated in every patient. Multibacillary status seems to be the main risk factor for kidney dysfunction in this disease. Different kinds of glomerulopathy have been described in association with leprosy. Specific treatment seems to impact on renal function improvement.

\section{RESUMO}

\section{Nefropatia da hanseníase: revisão dos aspectos clínicos e histopatológicos}

A hanseníase é doença crônica causada pelo Mycobacterium leprae, altamente incapacitante e com envolvimento sistêmico em alguns casos. O envolvimento renal tem sido relatado em todas as formas da doença, sendo mais frequente nas formas multibacilares. A apresentação clínica é variável e determinada pela reação do sistema imunológico do hospedeiro ao bacilo. Durante o curso da doença podem ocorrer os chamados estados reacionais, nos quais o sistema imune reage contra o bacilo, exacerbando as manifestações clínicas. Diferentes lesões renais tem sido descritas na hanseníase, incluindo glomerulonefrites, nefrite intersticial, amiloidose secundária e pielonefrite. O mecanismo exato que leva à glomerulonefrite na hanseníase ainda não está completamente esclarecido. O tratamento da hanseníase inclui o uso de rifampicina, dapsona e clofazimina. Prednisona e antiinflamatórios não-hormonais podem ser usados no controle dos episódios imunológicos agudos.

\section{REFERENCES}

1. Ahsan N, Wheeler DE, Palmer BF. Leprosy-associated renal disease: case report and review of the literature. J Am Soc Nephrol. 1995;5:1546-52.

2. Al-Mohaya SA, Coode PE, Alkhder AA, Al-Suhaibani MO. Renal granuloma and mesangial proliferative glomerulonephritis in leprosy. Int $\mathbf{J}$ Lepr Other Mycobact Dis. 1988;56:599-602.

3. Araújo MG. Hanseníase no Brasil. Rev Soc Bras Med Trop. 2003;36:373-82.

4. Ardalan M, Ghaffari A, Ghabili K, Shoja MM. Lepromatous leprosy in a kidney transplant recipient: a case report. Exp Clin Transplant. 2011;9:203-6.

5. Bernard JC, Vazquez CAJ. Visceral lesions in lepromatous leprosy. Study of sixty necropsies. Int J Lepr Other Mycobact Dis.1973;41:94-101.
6. Bhat RM, Prakash C. Leprosy: an overview of pathophysiology. Interdiscip Perspect Infect Dis. 2012;2012:181089.

7. Chugh KS, Damie PB, Kaur S, Shama BK, Kumar B, Sakhuja V, et al. Renal lesions in leprosy amongst north Indian patients. Postgrad Med J. 1983;59:707-11.

8. Chugh KS, Sakhuja V. End stage renal disease in leprosy. Int J Artif Organs. 1986;9:9-10

9. Cologlu AS. Immune complex glomerulonephritis in leprosy. Lepr Rev. 1979;50:213-22

10. Daher EF, Silva GB Jr, Cezar LC, Lima RS, Gurjão NH, Mota RM, et al. Renal dysfunction in leprosy: a historical cohort of 923 patients in Brazil. Trop Doct. 2011;41:148-50.

11. Date A, Johny KV. Glomerular subepithelial deposits in lepromatous leprosy. Am J Trop Med Hyg. 1975;24:853-6.

12. Date A, Thomas A, Mathai R, Johny KV. Glomerular pathology in leprosy. An electron microscopic study. Am J Trop Med Hyg. 1977;26:266-72.

13. Date A. The immunological basis of glomerular disease in leprosy: a brief review. Int $\mathbf{J}$ Lepr Other Mycobact Dis. 1982;50:351-3.

14. Date A, Neela P, Shastry JC. Membranoproliferative glomerulonephritis in a tropical environment. Ann Trop Med Parasitol. 1983;77:279-85.

15. Date A, Harihar S, Jeyavarthini SE. Renal lesions and other major findings in necropsies of 133 patients with leprosy. Int J Lepr Other Mycobact Dis. 1985;53:455-60.

16. Drutz DJ, Gutman RA. Renal tubular acidosis in leprosy. Ann Int Med. 1971;75:475-6.

17. Faria JBL. Significado da hematúria no diabetes mellitus. [Dissertação]. São Paulo: Escola Paulista de Medicina, Curso de Pós-graduação em Nefrologia; 1986.

18. Gelber RH. Erythema nodosum leprosum associated with azotemic acute glomerulonephritis and recurent haematuria. Int J Lepr Other Mycobact Dis. 1986;54:125-7.

19. Grover S, Bobhate SK, Chaubey BS. Renal abnormalities in leprosy. Lepr India. 1983;55:286-91

20. Gupta SC, Bajaj AK, Govil DC, Sinha SN, Kumar R. A study of percutaneous renal biopsy in lepromatous leprosy. Lepr India. 1981;53:179-84.

21. Gutman RA, Lu WH, Drutz DJ. Renal manifestations of leprosy: impaired acidification and concentration of urine in patients with leprosy. Am J Trop Med Hyg. 1973;22:223-8.

22. Humes HD, Weimberg JM. Toxic nephropathies, acute alergic or hypersensitivity tubulointerstitial nephropathy. In: Brenner BM, Rector FC Jr. The kidney. 3. ed. Philadelphia: WB Saunders; 1986. v. 2. p. 1515.

23. Iveson JM, McDougall AC, Leathem AJ, Harris HJ. Lepromatous leprosy presenting with polyarthritis, myositis, and immune-complex glomerulonephritis. Br Med J. 1975;3:619-21

24. Jain PK, Kumar S, Govil DC, Mittal VP, Agarwal N, Arora RC, et al. Renal changes in leprosy and its reactions. In: X International Congress of Nephrology. London; 1987. Abstracts. p. 69

25. Jayalakshmi P, Looi LM, Lim KJ, Rajogopalan K. Autopsy findings in 35 cases of leprosy in Malaysia. Int J Lepr Other Mycobact Dis. 1987;55:510-4.

26. Johny KV, Karat ABA, Rao PPS, Date A. Glomerulonephritis in leprosy: a percutaneous renal biopsy study. Lepr Rev. 1975;46:29-37.

27. Kanwar AJ, Bharija SC, Belhaj MS. Renal functional status in leprosy. Indian J Lepr. 1984;56:595-9.

28. Kean B, Childress ME. A summary of 103 autopsies on leprosy patients on the Isthmus of Panama. Int J Lepr. 1942;10:51-9. 
SILVA JUNIOR, G.B.; DAHER, E.F.; PIRES NETO, R.J.; PEREIRA, E.D.B.; MENESES, G.C.; ARAÚJO, S.M.H.A. \& BARROS, E.J.G. - Leprosy nephropathy: a review of clinical and histopathological features. Rev. Inst. Med. Trop. Sao Paulo, 57(1): 15-20, 2015.

29. Kirsztajn GM, Nishida SK, Silva MS, Ajzen H, Pereira AB. Renal abnormalities in leprosy. Nephron. 1993;65:381-4.

30. Kirsztajn GM, Pereira AB. Comprometimento renal na hanseníase. In: Cruz J, Barros RT. Atualidades em nefrologia 4. São Paulo: Sarvier; 1994. p. 144-53.

31. Lau G. A fatal case of drug-induced multi-organ damage in a patient with Hansen`s disease: dapsone syndrome or rifampicin toxicity? Forensic Sci Int. 1995;73:109-15.

32. Lomonte C, Chiarulli G, Cazzato F, Giammaria B, Marchio G, Losurdo N, et al. End stage renal disease in leprosy. J Nephrol. 2004;17:302-5.

33. MacAdam KP, Anders RS, Smith SR, Russel DA, Prince MA. Association of amyloidosis and erythema nodosum leprosum reactions and recurrent neutrophil leucocytosis in leprosy. Lancet. 1975;2(7935):572-3.

34. Madiwale CV, Mittal BV, Dixit M, Acharya VN. Acute renal failure due to crescentic glomerulonephritis complicating leprosy. Nephrol Dial Transplant. 1994;9:178-9.

35. Ministério da Saúde. Secretaria de Vigilância em Saúde. Guia de vigilância epidemiológica. $7^{\text {a }}$ ed. Brasília: Ministério da Saúde; 2009.

36. Mitsuda K, Ogawa M. A study of 150 autopsies on cases of leprosy. Int J Lepr. 1937;5:5360.

37. Mittal MM, Maheshwari HB, Kumar S. Renal lesions in leprosy. Arch Pathol. 1972;93: 8-12.

38. Nakayama EE, Ura S, Fleury RN, Soares V. Renal lesions in leprosy: a retrospective study of 199 autopsies. Am J Kidney Dis. 2001;38:26-30.

39. Nigam P, Pant KC, Kapoor KK, Kumar A, Saxena SP, Sharma SP, et al. Histo-functional status of kidney in leprosy. Indian J Lepr. 1986;58:567-75.

40. Oliveira RA, Silva GB Jr, Souza CJ, Vieira EF, Mota RM, Martins AM, et al. Evaluation of renal function in leprosy: a study of 59 consecutive patients. Nephrol Dial Transplant. $2008 ; 23: 256-62$.

41. Peter KS, Vijayakumar T, Vasudevan DM, Devi KR, Mathew MT, Gopinath T. Renal involvement in leprosy. Lepr India. 1981;53:163-78.

42. Phadnis MD, Mehta MC, Bharaswadker MS, Kolhatkar MK, Bulakh PN. Study of renal changes in leprosy. Int J Lepr Other Mycobact Dis. 1982;50:143-7.

43. Powell CS, Swan LL. Leprosy: pathologic changes observed in fifty consecutive necropsies. Am J Pathol. 1955;31:1131-47.

44. Ramanujam MK, Ramu G, Balakhrishnan S, Desikan KV. Nephrotic syndrome complicating lepromatous leprosy. India J Med Res. 1973;61:548-56.
45. Renault CA, Ernst JD. Mycobacterium leprae. In: Mandell: Mandell, Douglas, and Bennett's principles and practice of infectious diseases. $7^{\text {th }}$ ed. Philadelphia: Churchill Livingstone Elsevier; 2010. p. 3165-76.

46. Rodrigues LC, Lockwood DNJ. Leprosy now: epidemiology, progress, challenges, and research gaps. Lancet Infect Dis. 2011;11:464-70.

47. Sainani GS, Rao KV. Renal changes in leprosy. J Assoc Physicians India. 1974;22:659-64

48. Sengupta U, Ramu G, Sinha S, Ramanathan VD, Desikan KV. Immunoglobulins in the urine of leprosy patients. Int J Lepr Other Mycobact Dis. 1983;51:409-10.

49. Sharma A, Gupta R, Khaira A, Gupta A, Tiwari SC, Dinda AK. Renal involvement in leprosy: report of progression from diffuse proliferative to crescentic glomerulonephritis. Clin Exp Nephrol. 2010;14:268-71.

50. Shwe T. Renal involvement in leprosy. Trans R Soc Trop Med Hyg. 1972;66:26-7.

51. Silva Junior GB, Daher EF. Renal involvement in leprosy: retrospective analysis of 461 cases in Brazil. Braz J Infect Dis. 2006;10:107-12.

52. Silva Junior GB, Barbosa OA, Barros RM, Carvalho P dos R, Mendoza TR, Barreto DM, et al. Amiloídose e insuficiência renal crônica terminal associada à hanseníase. Rev Soc Bras Med Trop. 2010;43:474-6.

53. Singhal PC, Chugh KS, Kaur S, Malik AK. Acute renal failure in leprosy. Int J Lepr Other Mycobact Dis. 1977; 45:171-4.

54. Thunga G, Sam KG, Patel D, Khera K, Sheshadhri S, Bahuleyan S, et al. Effectivenes of hemodialysis in acute dapsone overdose: a case report. Am J Emerg Med. 2008;26:1070

55. Trindade MA, Palermo ML, Pagliari C, Valente N, Naafs B, Massarollo PC, et al. Leprosy in transplant recipients: report of a case after liver transplantation and review of the literature. Transpl Infect Dis. 2011;13:63-9.

56. Vallés M, Cantarelli C, Fort J, Carrera M. IgA nephropathy in leprosy. Arch Intern Med 1982;142:1238.

57. Vehaskari VM, Rapola J, Koskimies O, Savilahti E, Vilska J, Hallman N. Microscopic hematuria in school-children: epidemiology and clinicopathologic evaluation. J Pediatr. 1979;95(5 Pt 1):676-84.

58. World Health Organization. Global leprosy situation, 2010. Wkly Epidemiol Rec. 2010;85:337-48.

Received: 19 March 2014

Accepted: 2 June 2014 